\title{
The Effect of Oleander (Nerium oleander L.) Extracts on Seed Germination and Seedling Growth of Four Pistacia Species
}

\author{
Yusuf Nikpeyma1 ${ }^{1}$, Mehmet Hakkı Alma², Ferudun Koçer ${ }^{3 *}$ \\ ${ }^{1}$ Department of Horticulture, Faculty of Agriculture, Kahramanmaras Sütçü Imam University, 46040 Kahramanmaraş, Turkey \\ E-mail: nikpeyma@ksu.edu.tr, ORCID: https://orcid.org/0000-0001-7899-4023 \\ ${ }^{2}$ Department of Forest Products Engineering, Faculty of Forestry, Kahramanmaras Sütçü Imam University 46040, Kahramanmaraş, Turkey \\ E-mail: alma@ksu.edu.tr, ORCID: https://orcid.org/0000-0001-7011-3965 \\ ${ }^{3}$ Research and Development Centre for University-Industry-Public Relations (USKIM), Kahramanmaras Sütçü Imam University, 46040 \\ Kahramanmaraş, Turkey, Corresponding author, E-mail: kocerferudun@gmail.com, ORCID: https://orcid.org/0000-0002-8749-7106

\begin{tabular}{|c|c|}
\hline A R T I C L E I N F O & A B S T R A C T \\
\hline $\begin{array}{l}\text { Keywords: } \\
\text { Germination } \\
\text { Nerium oleander } \\
\text { Pistacia spp. } \\
\text { Extract } \\
\text { Gibberellic acid }\end{array}$ & $\begin{array}{l}\text { In this study, the effects of the extracts obtained from flower, stem, leaf, branch and their mixture } \\
\text { of Nerium oleander L. on the seed germination and seedling growth of four Pistacia species } \\
\text { (Pistacia terebinthus L., P. vera L., P. khinjuk Stocks., P. atlantica Desf. and P. terebinthus L.) } \\
\text { were investigated. Five hundred grams of N. oleander was taken from the plant parts and the } \\
\text { extracts were mixed with distilled water }(1.5 \mathrm{~L}) \text {. The extracts were applied to Pistacia species for } \\
24 \text { and } 48 \text { hours. The results showed that the extract had positive effects on their germination and } \\
\text { growths of the species mentioned above. The highest germination rate for all the Pistacia species } \\
\text { was obtained from the extracts of flower, while the lowest germination rate was recorded in the } \\
\text { mixture of all parts of } N \text {. oleander mentioned above. Moreover, the treatment time was found to } \\
\text { reduce the germination ratio. It was also found that the extracts from the stem of } N \text {. oleander were } \\
\text { the most effective on the stem height of the Pistacia species studied. It was followed by the extracts } \\
\text { from branches, leaves and flower, respectively. Furthermore, the findings indicated that the } \\
\text { extracts from the stem of } N \text {. oleander had pronounced effect on the stem diameter of the Pistacia } \\
\text { species studied. It was followed by the extracts from flower, leaves, and branches, respectively. } \\
\text { In general, the effects of the extracts from several parts of } N \text {. oleander on the germination and } \\
\text { other growing parameters were found to be almost comparable to those of synthetic promoter, } \\
\text { Gibberellic Acid }\left(\mathrm{GA}_{3} \text { ). }\right.\end{array}$ \\
\hline
\end{tabular}

(c) (1) () This work is licensed under Creative Commons Attribution 4.0 International License

\section{Introduction}

Oleander (Nerium oleander) is an ever green shrub or small tree in the dogbane family Apocynaceae. It is the only species currently classified in the genus Nerium. It is native to a broad area from Morocco and Portugal eastward through the Mediterranean region and southern Asia to Yunnan in southern China. It occurs typically around dry stream beds (Pankhurst, 2005; Imalı and Koçer, 2016).

Oleander leaf extract is used to treat congestive heart disease and applied topically to treat skin disorders. It should only be taken under supervision and dosage of a licensed herbalist and physician. Moreover, because of the high amount of silicate in the root of oleander, oleander is known as a very well fire retardant (Pankhurst, 2005). The most significant of toxins in the oleander plant are oleandrin and nervine, which are cardiac glycosides (Goetz, 1998; Imalı and Koçer, 2016; Khan, 2017). Ursolic and oleanolic acid are also found in Nerium oleander as one of the main components (Balkan et al., 2018; Cao et al., 2018).
The chemical secretion of one plant can inhibit the growth or germination of the same plant or different plants and microorganisms, which is called "allelopathy" (Rice, 1984; Latif et al., 2017). Allelochemicals are found everywhere in the nature for products and can be released from all plant tissues including leaves, stem, roots, flowers, seeds, rhizomes, pollen, bark and buds (Latif et al., 2017). So far, there have been many studies on the allelopathic properties of various plants (Alam, 1990; Alam et al., 1990; Ak et al., 1995; Alam et al., 1998; Friedman, 2017; Latif et al., 2017; Duke and Lydon, 2018; Einhellig, 2018; Shah et al., 2018). However, a few studies (Karaaltın et al., 2004) have been found on the effect of oleander extract on the germination of wheat plants. Allelopathic effects of oleander ( $N$. oleander) flower extract on seed germination and seedling development of Lolium multiflorum were investigated (Uslu et al., 2018). 
Some researchers have studied on the allelopathic effect of oleander on the 9 plant species: Abutilon theophrastii Medik., Amaranthus retroflexus L., Avena sterilis L., Conium maculatum L., Descurania sophia (L.) Webb. Ex Prant, Lepidium sativum L., Lolium perenne L., Rumex crispus L., Trifolium repens L. (Kadioglu and Yanar, 2004). It was found that oleander had positive effects on the germination of the plants mentioned above. Also, Karaaltin et al. (2004) reported that the oleander extracts had positive effects on the germination of wheat.

So far, no study has been done on the effect of oleander extracts on Pistacia species. Therefore, with this study, we aimed to find out the allelopathic effect of oleander extract on the germination and growth of the seed of four Pistacia species.

\section{Material and Methods}

\section{Material}

Oleander plants (Nerium oleander L.; Apocynaceae) were collected in Kahramanmaraş province which is located in the East Mediterrenean of Turkey. For germination and growth test, seed and seedlings of four Pistacia species (Pistacia vera, Pistacia terebinthus, Pistacia atlantica and Pistacia khinjuk) in the greenhouse were used.

\section{Preparation of the Extract}

Firstly, different parts of the oleander plant such as leaf, stem, flower, branch as well as their mixture, were washed under tap water and then cut into small pieces by scissors. Five hundred grams of each part were placed into glass beaker $(2.5 \mathrm{~L})$ and then mixed with distilled water $(1.5 \mathrm{~L})$. Finally, the resultant mixture was filtered by filter paper. The filtrate was used as an extract solution.

\section{Determination of Seed Germination and Growth}

For each Pistacia species studied herein and the extract of each part, at least 5 seeds (having 3 replications) were put into a glass jar and treated with the extracts for the treatment periods of 24 and $48 \mathrm{~h}$. For each Pistacia species and treatment period, seven treatments were conducted. Therefore, for each species and treatment time, 105 seeds were used. All the extract-treated seeds were compared with untreated ones and seeds treated with conventional $\mathrm{GA}_{3}$ (Gibberellic Acid) (250 ppm) used as reference promoter. For seed germination, stem diameter and height, the average number of the three replications were reported in this study.

The treated and untreated control seeds located in each box were transferred to greenhouse medium consisting of sand, soil and peat mixture having a weight ratio of 1:1:1 in boxes $(9 \times 5 \mathrm{~cm})$. Finally, the germination and development of the Pistacia species were recorded by following conventional methods. At least, the average of 10 measurements was reported as mean value in this study. The whole data were statistically analyzed by using Duncan's mean separation test $(\mathrm{P} \leq 0.05)$.

\section{Results and Discussion}

Table 1 shows the effect of the extracts obtained from various parts of $N$. oleander on the germination of the seeds of Pistacia species for $24 \mathrm{~h}$ in view of mean values of the germinated seed number, standard deviations and Duncan's Mean Separation Test. As can be seen from Table 1, the extracts of $N$. oleander play an important role on the germination of the seeds of all the Pistacia species studied here. On the basis of the extracts of all the parts of $N$. oleander, the extracts are found to be mostly effective on the seed germination of $P$. atlantica. It was followed by $P$. vera, $P$. terebinthus and $P$. khinjuk, respectively.

Table 1. Duncan's mean separation test results of the average number of the germinated seed of Pistacia species depending upon the extracts obtained from various parts of $N$. oleander for $24 \mathrm{~h}$ as well as $\mathrm{GA}_{3}$ and control

\begin{tabular}{|c|c|c|c|c|c|}
\hline \multirow{2}{*}{$\begin{array}{c}\text { Parts of } N \text {. } \\
\text { oleander }\end{array}$} & \multicolumn{5}{|c|}{ Average number of the germinated seed } \\
\hline & P. vera & P. khinjuk & P. atlantica & P. terebinthus & General means \\
\hline Control & $3.00 \pm 0.00^{\text {bcd* }}$ & $2.00 \pm 0.00^{\mathrm{ef}}$ & $2.67 \pm 0.58^{\text {cde }}$ & $2.00 \pm 0.00^{\mathrm{ef}}$ & $2.42 \pm 0.14^{\mathrm{c}}$ \\
\hline Leaf & $3.67 \pm 0.58^{\mathrm{ab}}$ & $3.00 \pm 0.00^{\mathrm{bcd}}$ & $3.00 \pm 0.00^{\mathrm{bcd}}$ & $2.33 \pm 0.58^{\mathrm{def}}$ & $3.00 \pm 0.29^{\mathrm{b}}$ \\
\hline Branch & $3.33 \pm 0.58^{\mathrm{abc}}$ & $2.33 \pm 0.58^{\mathrm{def}}$ & $3.33 \pm 0.58^{\mathrm{abc}}$ & $3.00 \pm 0.00^{\mathrm{bcd}}$ & $3.00 \pm 0.43^{\mathrm{b}}$ \\
\hline Stem & $3.67 \pm 0.58^{\mathrm{ab}}$ & $2.33 \pm 0.58^{\mathrm{def}}$ & $3.67 \pm 0.58^{\mathrm{ab}}$ & $3.00 \pm 0.00^{\mathrm{bcd}}$ & $3.17 \pm 0.43^{\mathrm{ab}}$ \\
\hline Flower & $3.33 \pm 0.58^{\mathrm{abc}}$ & $2.67 \pm 0.58^{\text {cde }}$ & $4.00 \pm 0.00^{\mathrm{a}}$ & $4.00 \pm 0.00^{\mathrm{a}}$ & $3.50 \pm 0.29^{\mathrm{a}}$ \\
\hline MAP & $1.67 \pm 0.58^{\mathrm{f}}$ & $3.00 \pm 0.00^{\mathrm{bcd}}$ & $3.33 \pm 1.15^{\mathrm{abc}}$ & $1.67 \pm 0.58^{\mathrm{f}}$ & $2.42 \pm 0.58^{\mathrm{c}}$ \\
\hline $\mathrm{GA}_{3}$ & $4.00 \pm 0.00^{\mathrm{a}}$ & $2.67 \pm 0.58^{\text {cde }}$ & $3.67 \pm 0.58^{\mathrm{ab}}$ & $2.67 \pm 0.58^{\mathrm{cde}}$ & $3.25 \pm 0.43^{\mathrm{ab}}$ \\
\hline General mean & $3.24 \pm 0.41^{\mathrm{a}}$ & $2.57 \pm 0.33^{\mathrm{b}}$ & $3.38 \pm 0.49^{\mathrm{a}}$ & $2.67 \pm 0.25^{\mathrm{b}}$ & \\
\hline
\end{tabular}

${ }^{*}$ Values with the same letters are not significantly different (Duncan's Mean Separation Test), MAP: Mixtures of all the parts

Table 2 Duncan's mean separation test results of the average number of the germinated seed of Pistacia species depending upon the extracts taken from various parts of $N$. oleander as well as $\mathrm{GA}_{3}$ and control for $48 \mathrm{~h}$.

\begin{tabular}{|c|c|c|c|c|c|}
\hline \multirow{2}{*}{$\begin{array}{c}\text { Parts of } N . \\
\text { oleander }\end{array}$} & \multicolumn{5}{|c|}{ Average number of the germinated seed } \\
\hline & P. vera & P. khinjuk & P. atlantica & P. terebinthus & General means \\
\hline Control & $3.33 \pm 0.58^{\mathrm{abc}}$ & $2.33 \pm 0.58^{\mathrm{def}}$ & $1.67 \pm 0.58^{\mathrm{fg}}$ & $3.00 \pm 0.00^{\mathrm{bcd}}$ & $2.58 \pm 0.43^{\mathrm{c}}$ \\
\hline Leaf & $2.00 \pm 0.00^{\mathrm{efg}}$ & $1.33 \pm 0.58^{\mathrm{g}}$ & $1.67 \pm 0.58^{\mathrm{fg}}$ & $1.67 \pm 0.58^{\mathrm{fg}}$ & $1.67 \pm 0.43^{\mathrm{d}}$ \\
\hline Branch & $3.33 \pm 0.58^{\mathrm{abc}}$ & $2.00 \pm 0.00^{\mathrm{efg}}$ & $3.00 \pm 0.00^{\mathrm{bcd}}$ & $3.00 \pm 0.00^{\mathrm{bcd}}$ & $2.83 \pm 0.14^{\mathrm{bc}}$ \\
\hline Stem & $3.33 \pm 0.58^{\mathrm{abc}}$ & $2.00 \pm 0.00^{\mathrm{efg}}$ & $3.67 \pm 0.58^{\mathrm{ab}}$ & $3.33 \pm 0.58^{\mathrm{abc}}$ & $3.08 \pm 0.43^{\mathrm{b}}$ \\
\hline Flower & $3.67 \pm 0.58^{\mathrm{ab}}$ & $1.67 \pm 0.58^{\mathrm{fg}}$ & $3.00 \pm 0.00^{\mathrm{bcd}}$ & $2.33 \pm 0.58^{\mathrm{def}}$ & $2.67 \pm 0.43^{c}$ \\
\hline MAP & $3.00 \pm 0.00^{\mathrm{bcd}}$ & $1.67 \pm 0.58^{\mathrm{fg}}$ & $2.67 \pm 0.58^{\mathrm{cde}}$ & $2.67 \pm 0.58^{\text {cde }}$ & $2.50 \pm 0.43^{\mathrm{c}}$ \\
\hline $\mathrm{GA}_{3}$ & $4.00 \pm 0.00^{\mathrm{a}}$ & $2.67 \pm 0.58^{\mathrm{cde}}$ & $4.00 \pm 0.00^{\mathrm{a}}$ & $3.33 \pm 0.58^{\mathrm{abc}}$ & $3.50 \pm 0.29 \mathrm{a}$ \\
\hline General mean & $3.24 \pm 0.33^{\mathrm{a}}$ & $1.95 \pm 0.41^{\mathrm{c}}$ & $2.81 \pm 0.33^{\mathrm{b}}$ & $2.76 \pm 0.41^{\mathrm{b}}$ & \\
\hline
\end{tabular}




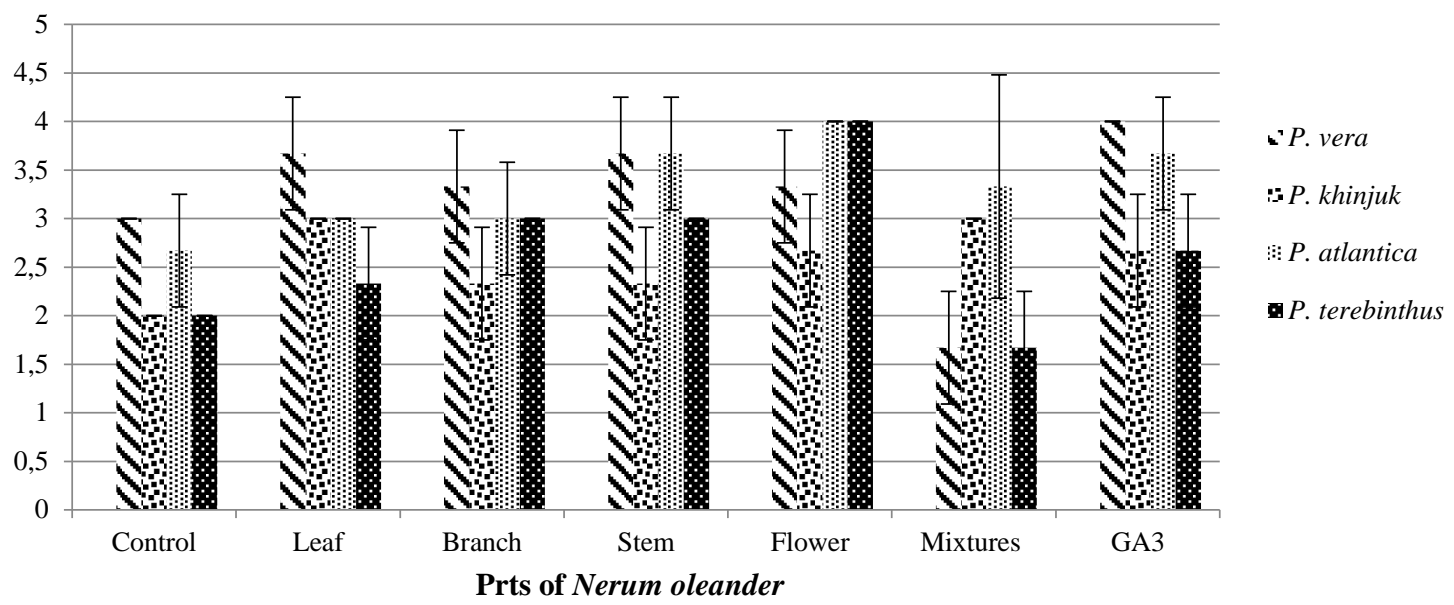

Figure 1 The effect of the extracts taken from various parts of $N$. oleander on the average germinated seed number of Pistacia species for $24 \mathrm{~h}$.

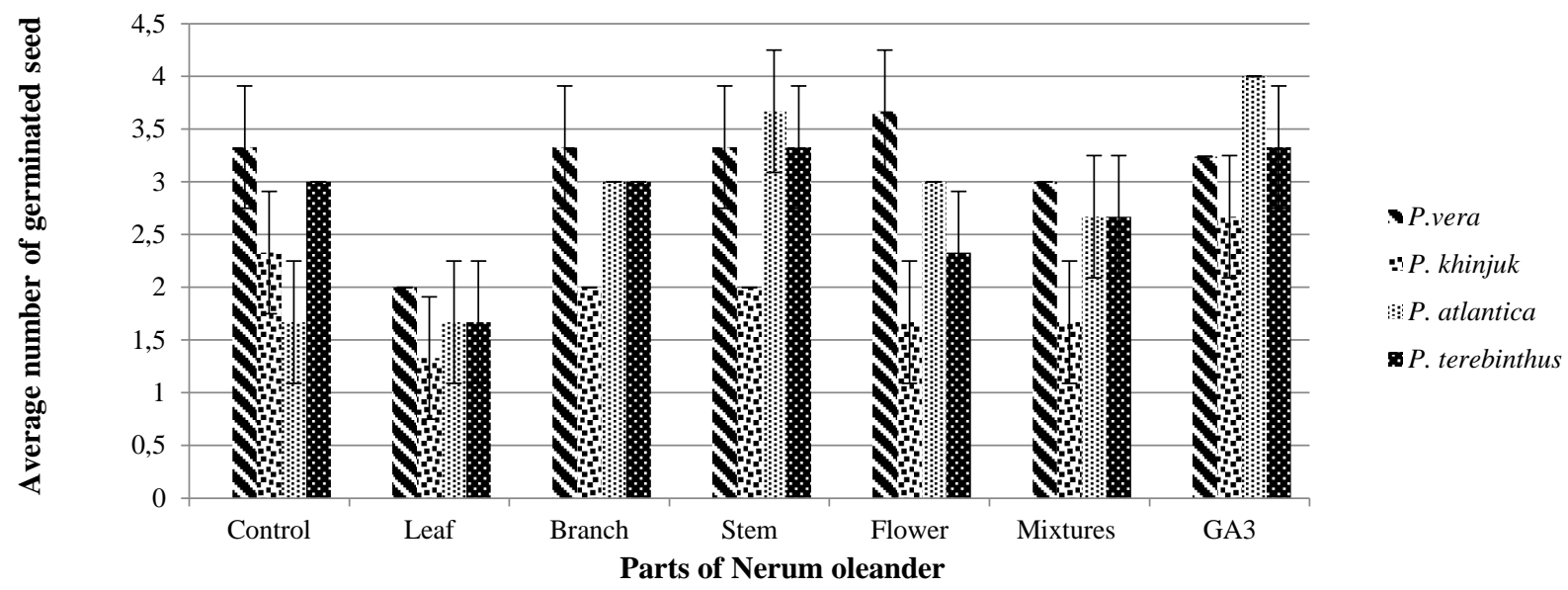

Figure 2 The effect of the extracts obtained from various parts of $N$. oleander on the average germinated seed number of Pistacia species for $48 \mathrm{~h}$.

As shown in Fig. 1, the extracts obtained from the flower of the oleander plant were the most effective part of $N$. oleander on the seed germination of the Pistacia species, which is followed by stem, leaves or branches and mixtures of all the parts studied, respectively. However, the $\mathrm{GA}_{3}$ (Gibberellic Acid) promoter resulted in the greatest seed germination.

Table 2 indicates the effect of the extracts taken from various parts of $N$. oleander on the germination of the seeds of Pistacia species for $48 \mathrm{~h}$ in view of mean values of seed, standard deviations and Duncan's Mean Separation Test. As can be seen from this table, all the extracts obtained from various parts of $N$. oleander have an important role on the germination of the seeds of all the Pistacia species studied here in comparison to control and somewhat to $\mathrm{GA}_{3}$ promoter.

For in vitro seed germination in the Pistacia species, different concentrations of $\mathrm{GA}_{3}$ were tested to provide the best rootstock production and percentages of seed germination of $P$. vera var. Siirt, $P$. khinjuk Stocks, $P$. atlantica Desf., $P$. terebinthus L. were detected as $80 \%$, $92 \%, 60 \%$ and $48 \%$, respectively (Onay et al., 2016). At the same time, seed germination of Lolium multiflorum was found to be $93 \%$ in $N$. oleander flower extracts by Uslu et al., (2018). The extracts of the flower are the most effective part of $N$. oleander on the seed germination of the Pistacia species, which is followed by $\mathrm{GA}_{3}$, stem, branches, leaves and the mixtures of all the parts studied, respectively.
When Table 1 is compared to Table 2, it can be said that the general mean values of the whole seed numbers of all the Pistacia species obtained from $48 \mathrm{~h}$ application are found to be less than those of the seed numbers for $24 \mathrm{~h}$. It is also clear from Fig. 2 that the number of seed germinated decreases when increasing the germination time. This phenomenon might be attributed to the side effect.

As seen from Fig. 2, on the basis of the extracts of all the parts of $N$. oleander, the extracts were most effective on the seeds germinated of $P$. vera. It was followed by $P$. atlantica, $P$. terebinthus and $P$. khinjuk, respectively. On the other hand, the highest number of seeds germinated were obtained from the flower extract and it was, followed by stem, branch and leaf extracts in P. vera for $48 \mathrm{~h}$. The mixture of all the extracts studied here gave average seed numbers as is expected. It is also important to notice that the leaf extract has a negative effect on the seed germination for all the Pistacia species for $48 \mathrm{~h}$ in comparison to control.

Table 3 demonstrates the effects of the extracts taken from various parts of $N$. oleander on the stem height of Pistacia species in view of mean values of seed, standard deviations and Duncan's Mean Separation Test. As can be seen from Table 3 and Fig 3, the whole extracts obtained from a various part of $N$. oleander show important role on the stem height of all the Pistacia species studied here in comparison to control. 
Table 3 Duncan's mean separation test results of the stem height of Pistacia species as functions of the extracts obtained from various parts of $N$. oleander as well as $\mathrm{GA}_{3}$ and control

\begin{tabular}{|c|c|c|c|c|c|}
\hline \multirow{2}{*}{$\begin{array}{c}\text { Parts of } N . \\
\text { oleander }\end{array}$} & \multicolumn{5}{|c|}{ Stem Height $(\mathrm{cm})$} \\
\hline & P. vera & P. khinjuk & P. atlantica & P. terebinthus & General means \\
\hline Control & $46.49 \pm 3.35^{\mathrm{ab}}$ & $31.19 \pm 1.86^{\mathrm{d}}$ & $32.11 \pm 1.99^{\mathrm{d}}$ & $24.43 \pm 3.05^{\mathrm{d}}$ & $33.55 \pm 2.56^{\mathrm{d}}$ \\
\hline Leaf & $57.78 \pm 2.04^{\mathrm{a}}$ & $35.23 \pm 4.56^{\mathrm{bc}}$ & $40.25 \pm 1.03^{\mathrm{bc}}$ & $29.14 \pm 0.96^{\mathrm{d}}$ & $40.6 \pm 2.15 b^{c}$ \\
\hline Branch & $58.46 \pm 1.53^{\mathrm{a}}$ & $36.31 \pm 4.78^{\mathrm{cd}}$ & $39.59 \pm 8.05^{\mathrm{abc}}$ & $35.13 \pm 4.61^{b c}$ & $42.37 \pm 4.74^{\mathrm{abc}}$ \\
\hline Stem & $59.16 \pm 0.84^{\mathrm{a}}$ & $39.92 \pm 5.91^{b c}$ & $41.24 \pm 10.2^{\mathrm{abc}}$ & $35.3 \pm 9.26 b^{c}$ & $43.91 \pm 6.55^{\mathrm{ab}}$ \\
\hline Flower & $52.81 \pm 3.95^{\mathrm{a}}$ & $34.84 \pm 4.92^{c}$ & $35.39 \pm 4.21^{\mathrm{c}}$ & $32.44 \pm 2.14^{\mathrm{d}}$ & $38.87 \pm 3.81^{\mathrm{c}}$ \\
\hline MAP & $48.84 \pm 1.42^{\mathrm{ab}}$ & $30.54 \pm 0.55^{\mathrm{d}}$ & $35.43 \pm 4.45^{\mathrm{d}}$ & $25.07 \pm 4.56^{\mathrm{d}}$ & $34.97 \pm 2.75^{\mathrm{d}}$ \\
\hline $\mathrm{GA}_{3}$ & $61.43 \pm 1.54^{\mathrm{a}}$ & $42.24 \pm 4.27^{\mathrm{ab}}$ & $44.56 \pm 6.75^{\mathrm{ab}}$ & $35.81 \pm 7.49^{\mathrm{bc}}$ & $46.01 \pm 5.01^{\mathrm{a}}$ \\
\hline General mean & $55 \pm 2.1^{\mathrm{a}}$ & $35.75 \pm 3.83^{\mathrm{b}}$ & $38.37 \pm 5.24^{\mathrm{b}}$ & $31.05 \pm 4.58^{c}$ & \\
\hline
\end{tabular}

"Values with the same letters are not significantly different (Duncan's Mean Separation Test), MAP: Mixtures of all the parts

Table 4 Duncan's mean separation test results of on the stem diameter of Pistacia species as functions of the extracts taken from various parts of $N$. oleander as well as $\mathrm{GA}_{3}$ and control

\begin{tabular}{l|lllll}
\hline \multicolumn{1}{c}{$\begin{array}{c}\text { Parts of } N . \\
\text { oleander }\end{array}$} & \multicolumn{5}{|c}{ Stem Diameter $(\mathrm{mm})$} \\
\cline { 2 - 6 } Control & P. vera & P. khinjuk & P. atlantica & P. terebinthus & General means \\
Leaf & $5.64 \pm 0.67^{\mathrm{b}}$ & $4.26 \pm 0.07^{\mathrm{c}}$ & $4.55 \pm 0.66^{\mathrm{c}}$ & $3.57 \pm 0.58^{\mathrm{c}}$ & $4.5 \pm 0.49^{\mathrm{c}}$ \\
Branch & $6.82 \pm 0.43^{\mathrm{a}}$ & $5.98 \pm 0.17^{\mathrm{b}}$ & $5.7 \pm 0.51^{\mathrm{b}}$ & $4.16 \pm 0.68^{\mathrm{c}}$ & $5.67 \pm 0.45^{\mathrm{b}}$ \\
Stem & $7.58 \pm 0.63^{\mathrm{a}}$ & $5.63 \pm 0.55^{\mathrm{b}}$ & $5.52 \pm 0.44^{\mathrm{b}}$ & $4.03 \pm 0.04^{\mathrm{c}}$ & $5.48 \pm 0.41^{\mathrm{b}}$ \\
Flower & $7.61 \pm 0.59^{\mathrm{a}}$ & $6.7 \pm 0.61^{\mathrm{a}}$ & $6.69 \pm 0.6^{\mathrm{a}}$ & $5.01 \pm 1^{\mathrm{b}}$ & $6.49 \pm 0.67^{\mathrm{a}}$ \\
MAP & $5.53 \pm 0.41^{\mathrm{b}}$ & $4.58 \pm 0.58^{\mathrm{c}}$ & $6.79 \pm 0.42^{\mathrm{a}}$ & $4.38 \pm 0.65^{\mathrm{c}}$ & $6.42 \pm 0.48^{\mathrm{a}}$ \\
GA $_{3}$ & $8.61 \pm 0.53^{\mathrm{a}}$ & $7.2 \pm 0.85^{\mathrm{a}}$ & $4.57 \pm 0.66^{\mathrm{c}}$ & $3.74 \pm 0.59^{\mathrm{c}}$ & $4.6 \pm 0.56^{\mathrm{c}}$ \\
General mean $^{\mathrm{a}}$ & $6.93 \pm 0.53^{\mathrm{a}}$ & $5.89 \pm 0.44^{\mathrm{b}}$ & $5.0 \pm 0.18^{\mathrm{a}}$ & $4.37 \pm 0.57^{\mathrm{c}}$ & $6.8 \pm 0.53^{\mathrm{a}}$ \\
\hline
\end{tabular}

"Values with the same letters are not significantly different (Duncan's Mean Separation Test), MAP: Mixtures of all the parts

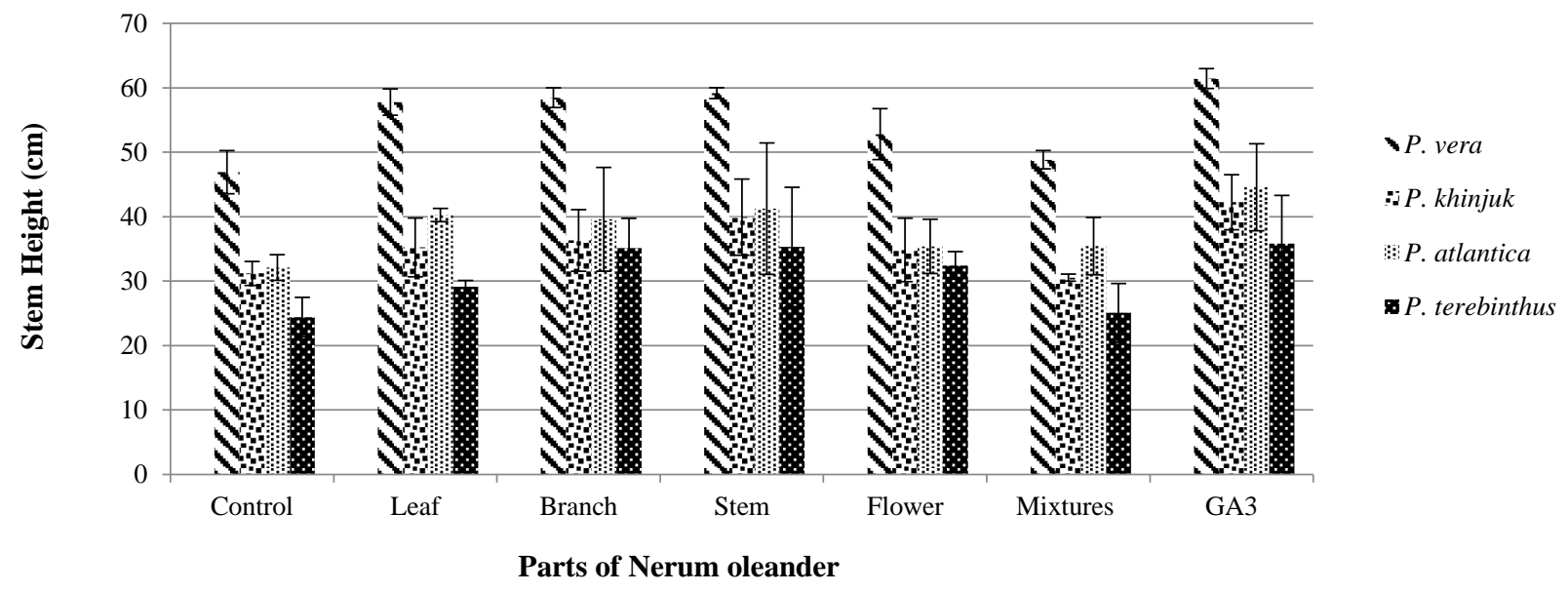

Figure 3 The effects of the extracts taken from various parts of $N$. oleander on the stem height of Pistacia species

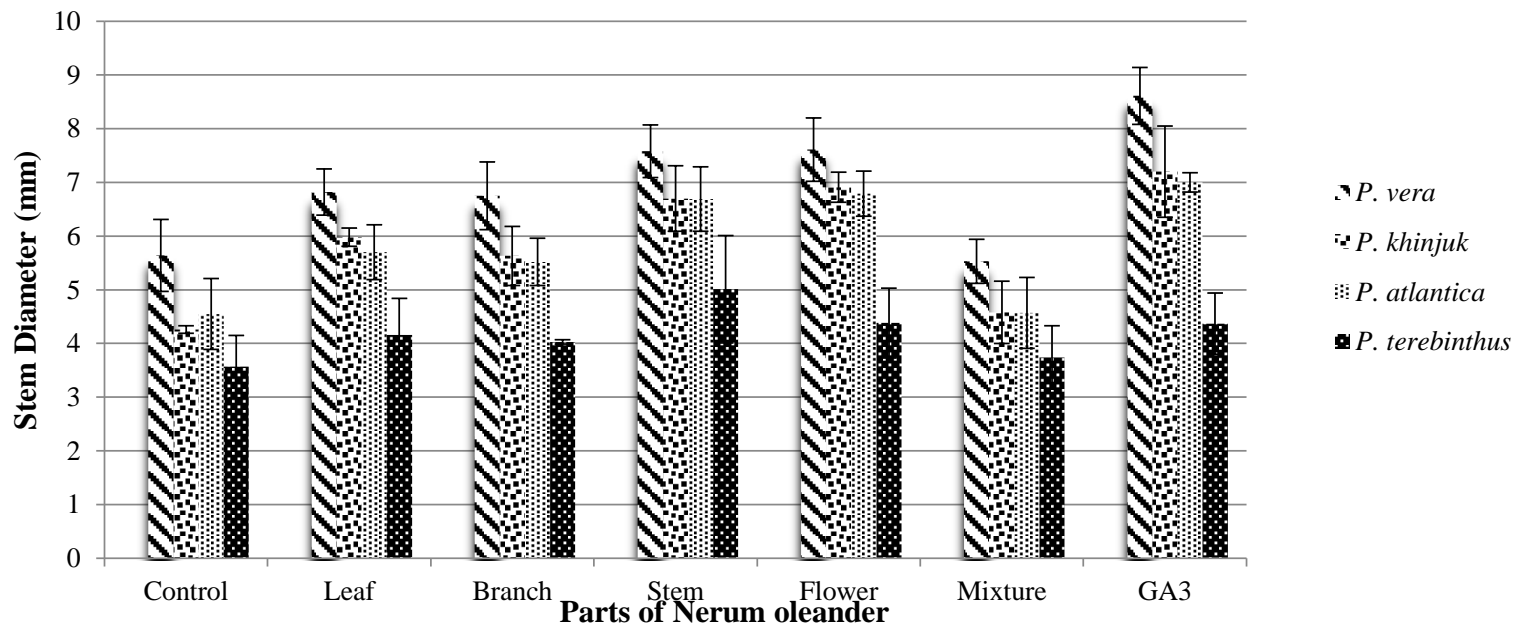

Figure 4 The effects of the extracts obtained from various parts of $N$. oleander on the stem diameter of Pistacia species 
The $10 \%$ and $7.5 \%$ Nerium oleander leaf extracts used for germination of Cyperus rotundus seeds were reported to be $90 \%$ more efficient in germination of Cyperus rotundus seeds (Al-Samarai et al., 2018). The extracts taken from the stem extract of $N$. oleander is determined to be the most efficient promoter on the stem height of the Pistacia species studied, and it was followed by the extracts obtained from branches, leaves and flower, respectively. In general, for all the extracts used herein, $P$. vera has the highest stem height. It was followed by $P$. atlantica, $P$. khinjuk and $P$. terebinthus, respectively. It is also interesting to report that there is no significant difference in stem height values between all the extracts and $\mathrm{GA}_{3}$ for P. vera (Table 3).

Table 4 depicts the effects of the extracts obtained from various parts of $N$. oleander on the stem diameter of Pistacia species in view of mean values of seed, standard deviations and Duncan's Mean Separation Test. As can be seen from Table 4 and Fig. 4 , the whole extracts taken from a various part of $N$. oleander are determined to be effective on the stem diameter of all the Pistacia species studied here in comparison to control. It is also clear from this table that the extracts from the stem extracts of $N$. oleander are the most effective promoter on the stem diameter of the Pistacia species studied and it was followed by the extracts obtained from flower, leaves and branches, respectively. Moreover, $P$. vera has the highest stem height and it is followed by $P$. khinjuk, $P$. atlantica and $P$. terebinthus, respectively. However, the effects of the extracts taken from various parts of $N$. oleander on the stem diameter are lower than $\mathrm{GA}_{3}$ promoter (see Fig. 4). It has been reported that different applications of gibberellic acid give successful results in seed germination and growth studies of P. khinjuk (Acar et al., 2017).

In this study, 250 ppm $\mathrm{GA}_{3}$ was used in addition to oleander extracts. Seeds were grown in a greenhouse environment. In a study conducted by Nikpeyma, (2016), germination of different Pistacia species applied $\mathrm{GA}_{3}$ was investigated in different environmental conditions.

As a result of the application on Pistacia species of $N$. oleander extract was obtained statistically significant results. In this study, it was determined that $N$. oleander extracts of different species of Pistacia made positive contributions to seed and seedling development compared to 250 ppm $\mathrm{GA}_{3}$ application.

\section{References}

Acar I, Yasar H, Ercisli S. 2017. Effects of Dormancy-Breaking Treatments on Seed Germination and Seedling Growth of Pistacia khinjuk Stocks Using As Rootstock For Pistachio Trees. Journal of Applied Botany and Food Quality 90, 191-196.

Ak BE, Özgüven AI, Nikpeyma Y. 1995. The Effect of $\mathrm{GA}_{3}$ Applications on Pistachio Nut Seed Germination and Seedling Growth. In I International Symposium on Pistachio. 419.pp. 115-120. DOI: 10.17660/ActaHortic.1995.419.17.

Alam SM, Ala AR, Naqvi SA, Ansari R. 1998. Effect of Aqueous Leaf Extract of Field Bindweed (Convolvulus arvensis L.) and Salinity on Growth of Wheat. Rachis. Barley and Wheat Newsletter 17: (1\&2), 49-51. ISSN : 0255-6421.

Alam SM, Azmi AR, Ali SA. 1990. Effect of Purple Nutsedge (Cyperus rotundus L.) Leaf Extracts on Germination and Seedling Growth of Wheat. Pakistan Journal of Science and Industrial Res. 33: 835.
Alam SM. 1990. Effect of Wild Plant Extracts on The Germination and Seedling Growth of Wheat. Rachis. 9: 1235 .

Al-Samarai GF, Mahdi WM, Al-Hilali, BM. 2018. Reducing Environmental Pollution By Chemical Herbicides Using Natural Plant Derivatives-Allelopathy Effect. Annals of Agricultural and Environmental Medicine, 25(3): 449-452.

Balkan İA, Doğan HT, Zengin G, Colak N, Ayaz FA, Gören AC, Kırmızıbekmez H, Yeşilada, E. 2018. Enzyme Inhibitory and Antioxidant Activities of Nerium oleander L. Flower Extracts and Activity Guided Isolation of The Active Components. Industrial Crops and Products, 112, 24-31.

Cao YL, Zhang MH, Lu YF, Li CY, Tang JS, Jiang, MM. 2018. Cardenolides From The Leaves of Nerium oleander. Fitoterapia, 127, 293-300.

Duke SO, Lydon J. 2018. The Role of Pesticides on Host Allelopathy and Their Effects on Allelopathic Compounds. In Pesticide Interactions in Crop Production (pp. 37-56). CRC Press.

Einhellig, FA. (2018). Allelopathy-A Natural Protection, Allelochemicals. In Handbook of Natural Pesticides: Methods (pp. 161-200). CRC Press.

Friedman, J. (2017). Allelopathy, Autotoxicity, and Germination. In Seed Development and Germination (pp. 629-644). Routledge.

Goetz RJ. 1998. Oleander, Indiana Plants Poisonous to Livestock and Pets. Cooperative Extension Service. Purdue University. Retrieved. 10-23.

Imalı A, Koçer F. 2016. Oleander (Nerium oleander L.) Seed as A Source for Fungal Aerosols. 1st International Black Sea Congress on Environmental Sciences (IBCESS). 329-334.

Kadioglu I, Yanar Y. 2004. Allelopathic Effects of Plant Extracts Against Seed Germination of Some Weeds. Asian Journal of Plant Sci. 3 (4): 472-475.

Karaaltin S, Idikut L, Uslu ÖS, Erol A. 2004. Effect of Root, Stem, Leaf and Bud Extracts of Oleander (Nerium oleander) on The Germination of Seed and Seedling Growth of Bean and Wheat. KSU Journal of Science and Engineering. 7(1).

Khan, AS. 2017. An Introduction to Medicinally Important Trees. In Medicinally Important Trees (pp. 1-20). Springer, Cham.

Latif S, Chiapusio G, Weston LA. 2017. Allelopathy and The Role of Allelochemicals In Plant Defence. In Advances in Botanical Research (Vol. 82, pp. 19-54). Academic Press.

Nikpeyma, Y. 2016. The Effects of $\mathrm{GA}_{3}$ Application in Different Environmental Conditions on The Survival Ability of The Seeds of Pistacia Species and Cultivars. In VII International Scientific Agriculture Symposium, "Agrosym 2016", 6-9 October 2016, Jahorina, Bosnia and Herzegovina. Proceedings. pp. 1604-1609

Onay A, Tilkat E, Süzerer V, Metin ÖK, Çiftçi YÖ, Kilinc FM, Koç İ, Şakiroğlu M, Yıldırım H, Altınkut Uncuoğlu A, Calar N. 2016. Rejuvenation of Mature Lentisk by Micrografting and Evaluation of Genetic Stability. Turkish Journal of Biology, 40(4), 781-796.

Pankhurst, R. 2005. Nerium oleander L. Flora Europaea. Royal. Rice, E. L. 1984. 'Allelopathy'. 2nd Edn. Academic Press: Orlando, FL, USA.

Shah N, Ahmad I, Imran M, Gul H, Babar MJ, Shah WA, Anwar S. 2018. 44. Allelopathic Effect of Callistemon lanceolatus DC. Against Two Cultivars of Triticum aestivum L. Pure and Applied Biology (PAB), 7(2), 783-790.

Uslu, ÖS, Gedik O, Kaya AR, Erol A, Khan MA, Taşsever MN, Türkkaya E. 2018. Allelopathic Effects of Flower Extract of Oleander (Nerium oleander) on the Germination of Seed and Seedling Growth of Lolium multiflorum. Iğdır Univ. J. Inst. Sci. \& Tech. 8(1): 309-317. 